\title{
Crystal structure of $\mathrm{Cu}_{2} \mathrm{Se}$
}

Lubomir GULAY ${ }^{1}$, Marek DASZKIEWICZ ${ }^{2}$, Oksana STROK ${ }^{3}$, Adam PIETRASZKO ${ }^{2}$

${ }^{1}$ Department of Ecology and Protection of Environment, Lesya Ukrainka Volyn National University, Voli Ave. 13, 43009 Lutsk, Ukraine

${ }^{2}$ Institute of Low Temperature and Structure Research, Polish Academy of Sciences, P. O. Box 1410, 50-950 Wroctaw, Poland

${ }^{3}$ Department of Inorganic and Physical Chemistry, Lesya Ukrainka Volyn National University, Voli Ave. 13, 43009 Lutsk, Ukraine

*Corresponding author.Tel.: +038-067-3326625; e-mail: gulay@o2.pl

Received February 14, 2011; accepted December 28, 2011; available on-line August 17, 2012

The crystal structures of the low-temperature (space group $C 2 / c$, Pearson symbol $m S 144, a=7.1379(4) \AA$, $\left.b=12.3823(7) \AA, c=27.3904(9) \AA, \beta=94.308^{\circ}, R_{I}=0.0765\right)$ and high-temperature (space group $F m-3 m$, Pearson symbol $c F 12, a=5.859(1) \AA, R 1=0.0391$ ) modifications of $\mathrm{Cu}_{2} \mathrm{Se}$ were determined by means of $\mathrm{X}$-ray powder and single crystal diffraction. The basic features of the two modifications are similar. The Se atoms are stacked in a close-packed arrangement with the layers in the sequence $A B C$. The $\mathrm{Cu}$ atoms are distributed over all tetrahedral interstices. The positions of $\mathrm{Cu}$ are completely ordered in the lowtemperature modification, whereas they are disordered in the high-temperature modification.

Cu compounds / Chalcogenides / X-ray single crystal diffraction / X-ray powder diffraction / Crystal structures

\section{Introduction}

Chalcogenides have attracted great interest over the last years due to their thermal, electrical and optical properties. Investigation of the crystal structures of chalcogenides is an important step in the search for new materials $[1,2]$.

The existence of two modifications of the $\mathrm{Cu}_{2} \mathrm{Se}$ compound has been known for a long time. However, suffering from the complexity of the twinning, the crystal structure of the low-temperature (LT) modification was not yet been determined. For example, a monoclinic unit cell $(a=14.087 \AA$, $b=20.481 \AA, c=4.145 \AA, \beta=90.38^{\circ}$ ) was proposed in [3]. The LT modification was also examined in [4], using X-ray single crystal and electron diffraction. On the contrary, numerous refinements have been performed of the crystal structure of the hightemperature (HT) modification (space group $F m-3 m$, $a=5.787 \AA$ in [5]) because of its superionic properties.

\section{Experimental}

A sample with the nominal composition $\mathrm{Cu}_{2} \mathrm{Se}$ was prepared by sintering the elements of purity better than 99.9 wt.\% in evacuated quartz tubes. The synthesis was carried out in a tube resistance furnace. The ampoule was first heated at a rate of $30 \mathrm{~K} \mathrm{~h}^{-1}$ up to $1420 \mathrm{~K}$, and then kept at this temperature for 3 hours. Afterwards, the sample was slowly cooled $\left(10 \mathrm{~K} \mathrm{~h}^{-1}\right)$ to $870 \mathrm{~K}$, and annealed at this temperature for 720 hours. Subsequently, the ampoule was quenched in air.

A small single crystal of $\mathrm{Cu}_{2} \mathrm{Se}$ suitable for crystal structure investigations was selected from the sample. $\mathrm{X}$-ray diffraction data were collected on a KUMA Diffraction KM-4 four-circle diffractometer equipped with a CCD detector, using graphitemonochromatized $\operatorname{Mo} K_{\alpha}$ radiation $(\lambda=0.71073 \AA)$. High-temperature measurements of the $\mathrm{Cu}_{2} \mathrm{Se}$ single crystal were performed up to $415 \mathrm{~K}$ using KUMA Diffraction equipment. The raw data were treated with the CrysAlis Data Reduction program [6] taking into account an absorption correction. The intensities of the reflections were corrected for Lorentz and polarization effects. The crystal structure was solved by the Patterson method and refined by the full-matrix least-squares method using SHELXL-97 [7].

The X-ray powder diffraction pattern of $\mathrm{Cu}_{2} \mathrm{Se}$ for the crystal structure refinement was recorded using a X'Pert PRO powder diffractometer $\left(\mathrm{Cu} K_{\alpha}\right.$ radiation, $10^{\circ} \leq 2 \theta \leq 100^{\circ}$, step scan mode with a step size of 
$0.02^{\circ}$ and counting time of $3597 \mathrm{~s}$ per data point). The crystal structure determination was performed using the CSD [8] program.

\section{Results and discussion}

The crystal structure of the low-temperature (LT) phase of $\mathrm{Cu}_{2} \mathrm{Se}$ was investigated in two steps. At the first step, a small single crystal of $\mathrm{Cu}_{2} \mathrm{Se}$ was selected from the sample of the respective composition. A model of the structure was obtained from X-ray single crystal diffraction data $(R 1 \approx 0.14)$ at room temperature. At the second step, X-ray powder diffraction data were used for the refinement. The model of the crystal structure obtained from the single crystal investigation was used for the powder diffraction refinement. The cell parameters and experimental details of the powder diffraction refinement of $\mathrm{LT}-\mathrm{Cu}_{2} \mathrm{Se}$ are given in Table 1 , whereas the atomic coordinates and displacement parameters are listed in Table 2. Twelve $\mathrm{Cu}$ positions and six $\mathrm{Se}$ positions were determined. All the positions are fully occupied. Since the structure of the LT phase is complex, the values of the displacement parameters were fixed. The experimental and calculated diffractograms and the corresponding difference diagram are shown in Fig. 1.

The single crystal was also investigated above room temperature. The dependence of the lattice parameters on temperature is shown in Fig. 2. The lattice parameters $a$ and $b$ increase, however, the parameter $c$ decreases with increasing temperature; an increase of the unit cell volume is observed. The lowtemperature modification of $\mathrm{Cu}_{2} \mathrm{Se}$ transforms to the high-temperature (HT) modification above $\sim 400 \mathrm{~K}$.
A single crystal structure determination was performed on data collected at $415 \mathrm{~K}$. As a result of the crystal structure solution and refinement, one Se position and three $\mathrm{Cu}$ positions were found. The arrangement of the Se atoms is ordered, whereas the $\mathrm{Cu}$ atoms are disordered. The displacement parameters of $\mathrm{Cu}$ were determined in isotropic approximation. The cell parameters and experimental details of the crystal structure determination for the HT phase of $\mathrm{Cu}_{2} \mathrm{Se}$ are given in Table 3 , whereas the atomic coordinates and displacement factors are listed in Table 4. One additional position of $\mathrm{Cu}$ was observed in the structure of $\mathrm{HT}-\mathrm{Cu}_{2} \mathrm{Se}$ in the present work, when compared with the results published in [5].

Table 1 Crystallographic data and experimental details for $\mathrm{LT}-\mathrm{Cu}_{2} \mathrm{Se}$.

\begin{tabular}{l|l}
\hline Compound & $\mathrm{Cu}_{2} \mathrm{Se}$ \\
Space group & $C 2 / c(\mathrm{No} .15)$ \\
$a(\AA)$ & $7.1379(4)$ \\
$b(\AA)$ & $12.3823(7)$ \\
$c(\AA)$ & $27.3904(9)$ \\
$\beta\left(\left(^{\circ}\right)\right.$ & $94.308(5)$ \\
Cell volume $\left(\AA^{3}\right)$ & $2414.0(4)$ \\
Number of formula units per unit cell & 48 \\
Calculated density $\left(\mathrm{g} / \mathrm{cm}^{3}\right)$ & 6.803 \\
Radiation and wavelength & $\mathrm{Cu} 1.54178 \AA$ \\
Diffractometer & $\mathrm{X}$ Pert PRO \\
Mode of refinement & Full profile \\
Number of atom sites & 18 \\
Structure solution and refinement & $\mathrm{CSD}$ \\
$R_{\mathrm{I}}$ & 0.0765 \\
$R_{\mathrm{p}}$ & 0.1237 \\
Texture axis and parameter & {$[001] 1.062(9)$} \\
\hline
\end{tabular}

Table 2 Atomic coordinates and isotropic temperature factors for LT- $\mathrm{Cu}_{2} \mathrm{Se}$.

\begin{tabular}{l|c|c|c|c|c}
\hline \multicolumn{1}{c|}{ Atom } & Position & $x / a$ & $y / b$ & $z / c$ & $B_{\text {iso }}\left(\AA^{2}\right)$ \\
\hline Cu1 & $8 f$ & $0.364(2)$ & $0.075(2)$ & $0.3198(6)$ & 2.0 \\
Cu2 & $8 f$ & $0.890(2)$ & $0.915(2)$ & $0.4284(5)$ & 2.0 \\
Cu3 & $8 f$ & $0.881(3)$ & $0.245(1)$ & $0.3221(6)$ & 2.0 \\
Cu4 & $8 f$ & $0.405(2)$ & $0.077(2)$ & $0.4562(5)$ & 2.0 \\
Cu5 & $8 f$ & $0.226(3)$ & $0.205(1)$ & $0.3982(7)$ & 2.0 \\
Cu6 & $8 f$ & $0.903(3)$ & $0.241(1)$ & $0.4293(6)$ & 2.0 \\
Cu7 & $8 f$ & $0.623(2)$ & $0.905(2)$ & $0.3514(5)$ & 2.0 \\
Cu8 & $8 f$ & $0.865(2)$ & $0.911(2)$ & $0.2886(5)$ & 2.0 \\
Cu9 & $8 f$ & $0.526(3)$ & $0.275(1)$ & $0.3567(6)$ & 2.0 \\
Cu10 & $8 f$ & $0.654(2)$ & $0.089(2)$ & $0.3918(6)$ & 2.0 \\
Cu11 & $8 f$ & $0.991(2)$ & $0.053(1)$ & $0.3552(5)$ & 2.0 \\
Cu12 & $8 f$ & $0.263(2)$ & $0.936(1)$ & $0.3980(5)$ & 2.0 \\
Se1 & $8 f$ & $0.057(2)$ & $0.077(1)$ & $0.4448(4)$ & 1.0 \\
Se2 & $8 f$ & $0.694(2)$ & $0.083(1)$ & $0.3037(4)$ & 1.0 \\
Se3 & $8 f$ & $0.201(2)$ & $0.237(1)$ & $0.3104(4)$ & 1.0 \\
Se4 & $8 f$ & $0.082(2)$ & $0.747(1)$ & $0.4445(4)$ & 1.0 \\
Se5 & $8 f$ & $0.571(2)$ & $0.902(1)$ & $0.4409(4)$ & 1.0 \\
Se6 & $8 f$ & $0.198(2)$ & $0.912(1)$ & $0.3082(4)$ & 1.0
\end{tabular}




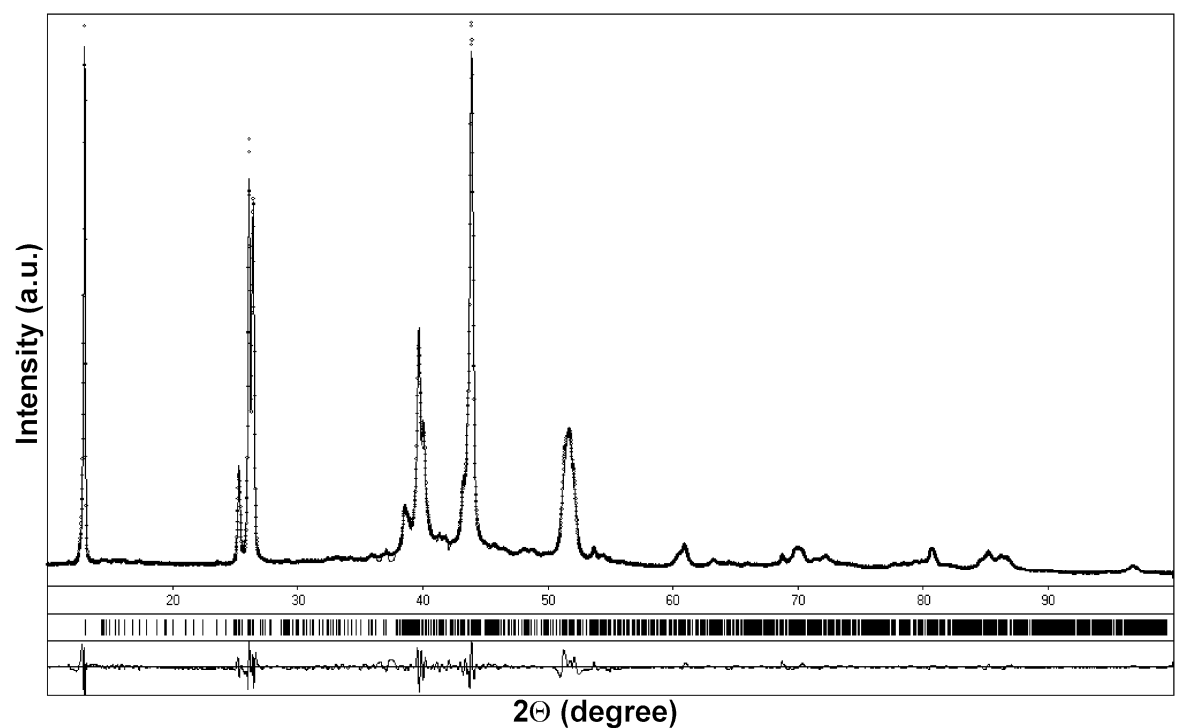

Fig. 1 Experimental and calculated diffractograms and the corresponding difference diagram for LT-Cu $\mathrm{Ce}_{2}$.

Table 3 Crystallographic data and experimental details for $\mathrm{HT}-\mathrm{Cu}_{2} \mathrm{Se}$.

\section{Compound}

Formula weight

Space group

$a(\AA)$

Volume $\left(\AA^{3}\right)$

Number of formula units per unit cell

Measurement temperature

Calculated density $\left(\mathrm{g} / \mathrm{cm}^{3}\right)$

Absorption coefficient $\left(\mathrm{mm}^{-1}\right)$

$F(000)$

Crystal color

Crystal size (mm)

$\theta$ range for data collection

Index ranges

\section{Reflections collected}

Independent reflections

Refinement method

Data/restraints/parameters

Goodness-of-fit on $F^{2}$

Final $R$ indices $[I>2 \sigma(I)]$

$R$ indices (all data)

Largest difference peak and hole $\left(\mathrm{e} / \AA^{3}\right)$

\section{$\mathrm{Cu}_{2} \mathrm{Se}$}

206.04

Fm-3m (No. 225)

$5.859(1)$

201.1(1)

4

415

6.803

38.712

368

black

$0.10 \times 0.06 \times 0.05$

6.03-29.02

$-7 \leq h \leq 7$

$-7 \leq k \leq 8$

$-7 \leq l \leq 8$

535

$26\left[R_{\text {int. }}=0.0870\right]$

Full-matrix least-squares on $F^{2}$

26/0/7

1.295

$R 1=0.0391, w R 2=0.1008$

$R 1=0.0391, w R 2=0.1008$

0.883 and -0.708

Table 4 Atomic coordinates and displacement factors for $\mathrm{HT} \mathrm{Cu}_{2} \mathrm{Se}$.

\begin{tabular}{l|l|l|l|l|l|l|l|l|l|l|l|l}
\hline Atom & Position & \multicolumn{1}{|c|}{$x / a$} & $y / b$ & $z / c$ & Occ. & $U_{\text {eq }}\left(\AA^{2}\right)$ & $U_{11}\left(\AA^{2}\right)$ & $U_{22}\left(\AA^{2}\right)$ & $U_{33}\left(\AA^{2}\right)$ & $\begin{array}{c}U_{23} \\
\left(\AA^{2}\right)\end{array}$ & $\begin{array}{c}U_{13} \\
\left(\AA^{2}\right)\end{array}$ & $\begin{array}{c}U_{12} \\
\left(\AA^{2}\right)\end{array}$ \\
\hline $\mathrm{Cu} 1$ & $8 c$ & $1 / 4$ & $1 / 4$ & $1 / 4$ & 0.31 & $0.040(2)$ & & & & & & \\
$\mathrm{Cu} 2$ & $32 f$ & $0.309(1)$ & $x$ & $x$ & 0.14 & $0.063(3)$ & & & & & & \\
$\mathrm{Cu} 3$ & $32 f$ & $0.384(5)$ & $x$ & $x$ & 0.03 & $0.05(1)$ & & & & & & \\
$\mathrm{Se}$ & $4 a$ & 0 & 0 & 0 & 1 & $0.037(1)$ & $0.037(1)$ & $0.037(1)$ & $0.037(1)$ & 0 & 0 & 0 \\
\hline
\end{tabular}




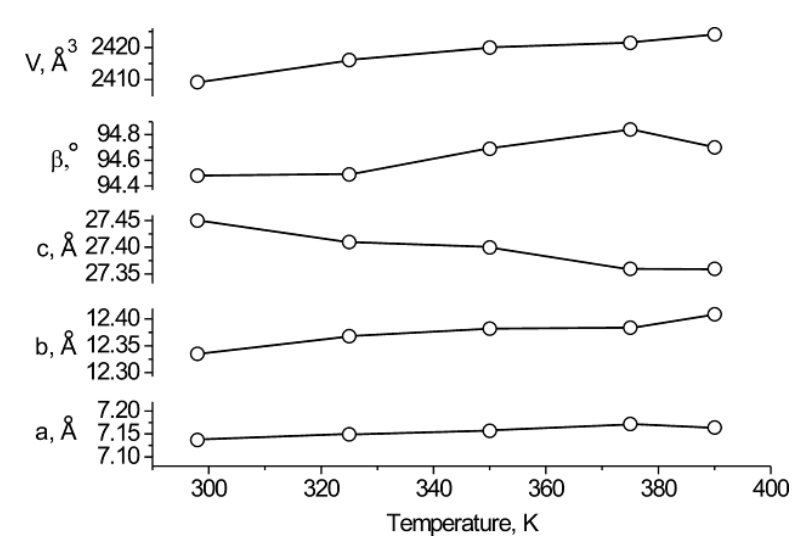

Fig. 2 Variation of the lattice parameters with temperature for $\mathrm{LT}-\mathrm{Cu}_{2} \mathrm{Se}$.

Table 5 Interatomic distances $(\delta)$ and coordination numbers $(\mathrm{CN})$ of the $\mathrm{Cu}$ atoms in the structure of LT- $\mathrm{Cu}_{2} \mathrm{Se}$.

\begin{tabular}{|c|c|c|c|}
\hline & $\mathrm{oms}$ & $\delta(\AA)$ & $\mathrm{CN}$ \\
\hline $\mathrm{Cu} 1$ & $\begin{array}{l}-1 \mathrm{Se} 3 \\
-1 \mathrm{Se} 6 \\
-1 \mathrm{Se} 2\end{array}$ & $\begin{array}{l}2.32(2) \\
2.35(3) \\
2.43(2)\end{array}$ & 3 \\
\hline $\mathrm{Cu} 2$ & $\begin{array}{l}-1 \mathrm{Se} 5 \\
-1 \mathrm{Se} 1 \\
-1 \mathrm{Se} 4 \\
\end{array}$ & $\begin{array}{l}2.33(2) \\
2.37(3) \\
2.50(3)\end{array}$ & 3 \\
\hline $\mathrm{Cu} 3$ & $\begin{array}{l}-1 \mathrm{Se} 3 \\
-1 \mathrm{Se} 2 \\
-1 \mathrm{Se} 6\end{array}$ & $\begin{array}{l}2.33(3) \\
2.45(2) \\
2.46(2)\end{array}$ & 3 \\
\hline $\mathrm{Cu} 4$ & $\begin{array}{l}-1 \mathrm{Se} 1 \\
-1 \mathrm{Se} 4 \\
-1 \mathrm{Se} 5 \\
\end{array}$ & $\begin{array}{l}2.47(2) \\
2.50(2) \\
2.51(3)\end{array}$ & 3 \\
\hline $\mathrm{Cu} 5$ & $\begin{array}{l}-1 \mathrm{Se} 1 \\
-1 \mathrm{Se} 3 \\
\end{array}$ & $\begin{array}{l}2.42(2) \\
2.43(2)\end{array}$ & 2 \\
\hline Cu6 & $\begin{array}{l}-1 \mathrm{Se} 5 \\
-1 \mathrm{Se} 1 \\
-1 \mathrm{Se} 4 \\
\end{array}$ & $\begin{array}{l}2.34(2) \\
2.34(3) \\
2.36(3)\end{array}$ & 3 \\
\hline $\mathrm{Cu} 7$ & $\begin{array}{l}-1 \mathrm{Se} 3 \\
-1 \mathrm{Se} 5 \\
-1 \mathrm{Se} 2 \\
\end{array}$ & $\begin{array}{l}2.44(2) \\
2.51(2) \\
2.63(3)\end{array}$ & 3 \\
\hline $\mathrm{Cu} 8$ & $\begin{array}{l}-1 \mathrm{Se} 6 \\
-1 \mathrm{Se} 2 \\
-1 \mathrm{Se} 3 \\
-1 \mathrm{Se} 6 \\
\end{array}$ & $\begin{array}{l}2.40(2) \\
2.51(3) \\
2.54(2) \\
2.66(2) \\
\end{array}$ & 4 \\
\hline $\mathrm{Cu} 9$ & $\begin{array}{l}-1 \mathrm{Se} 4 \\
-1 \mathrm{Se} 6 \\
-1 \mathrm{Se} 3 \\
\end{array}$ & $\begin{array}{l}2.43(2) \\
2.53(2) \\
2.60(3)\end{array}$ & 3 \\
\hline $\mathrm{Cu} 10$ & $\begin{array}{l}-1 \mathrm{Se} 2 \\
-1 \mathrm{Se} 4 \\
\end{array}$ & $\begin{array}{l}2.45(2) \\
2.51(2) \\
\end{array}$ & 2 \\
\hline $\mathrm{Cu} 11$ & $\begin{array}{l}-1 \mathrm{Se} 1 \\
-1 \mathrm{Se} 2 \\
-1 \mathrm{Se} 6 \\
\end{array}$ & $\begin{array}{l}2.48(2) \\
2.48(2) \\
2.67(2)\end{array}$ & 3 \\
\hline $\mathrm{Cu} 12$ & $\begin{array}{l}-1 \mathrm{Se} 5 \\
-1 \mathrm{Se} 6 \\
-1 \mathrm{Se} 1\end{array}$ & $\begin{array}{l}2.45(2) \\
2.48(2) \\
2.67(2)\end{array}$ & 3 \\
\hline
\end{tabular}

Relevant interatomic distances and coordination numbers $(\mathrm{CN})$ of the atoms in the low-temperature and high-temperature modifications of $\mathrm{Cu}_{2} \mathrm{Se}$ are listed in Tables 5 and 6, respectively. The values of the $\mathrm{Cu}-\mathrm{Se}$ distances correlate well with the sum of the ionic radii [9]. The $\mathrm{Se}$ atoms in the structure of LT$\mathrm{Cu}_{2} \mathrm{Se}$ are stacked in a close-packed arrangement with the layers in the sequence $A B C$ (Fig. 3). The $\mathrm{Cu}$ atoms are distributed over all the tetrahedral interstices. For most of the tetrahedrons the $\mathrm{Cu}$ atoms are shifted from the center of the polyhedron to one of the triangular faces or to an edge of the tetrahedron. Two Se atoms surround each of the $\mathrm{Cu} 5$ and $\mathrm{Cu} 10$ atoms, whereas tetrahedral surrounding exists only for the $\mathrm{Cu} 8$ atom. The remaining symmetry-independent copper atoms are located close to the plane of a triangular face $(\mathrm{CN}=3)$. The crystal structure of LT- $\mathrm{Cu}_{2} \mathrm{Se}$ is related to the structure of the recently investigated compound $\mathrm{Cu}_{2} \mathrm{SnSe}_{3}$ [10] (Fig. 4). The Se atoms in the structure of $\mathrm{Cu}_{2} \mathrm{SnSe}_{3}$ are also stacked in a close-packed arrangement with the layers in the sequence $A B C$. However, the $\mathrm{Cu}$ and $\mathrm{Sn}$ atoms occupy only half of the tetrahedral interstices. The structure of $\mathrm{Cu}_{2} \mathrm{SnSe}_{3}$, consisting of 96 atoms per unit cell $32 \mathrm{Cu}+16 \mathrm{Sn}+48 \mathrm{Se}$, can be obtained from the structure of $\mathrm{LT}-\mathrm{Cu}_{2} \mathrm{Se}$ (144 atoms per unit cell: $96 \mathrm{Cu}+48 \mathrm{Se}$ ) by replacement of $64 \mathrm{Cu}$ atoms by 16 $\mathrm{Sn}$ atoms. This substitution can be realized according to the relation $4 \mathrm{Cu}^{+} \rightarrow 1 \mathrm{Sn}^{4+}$.

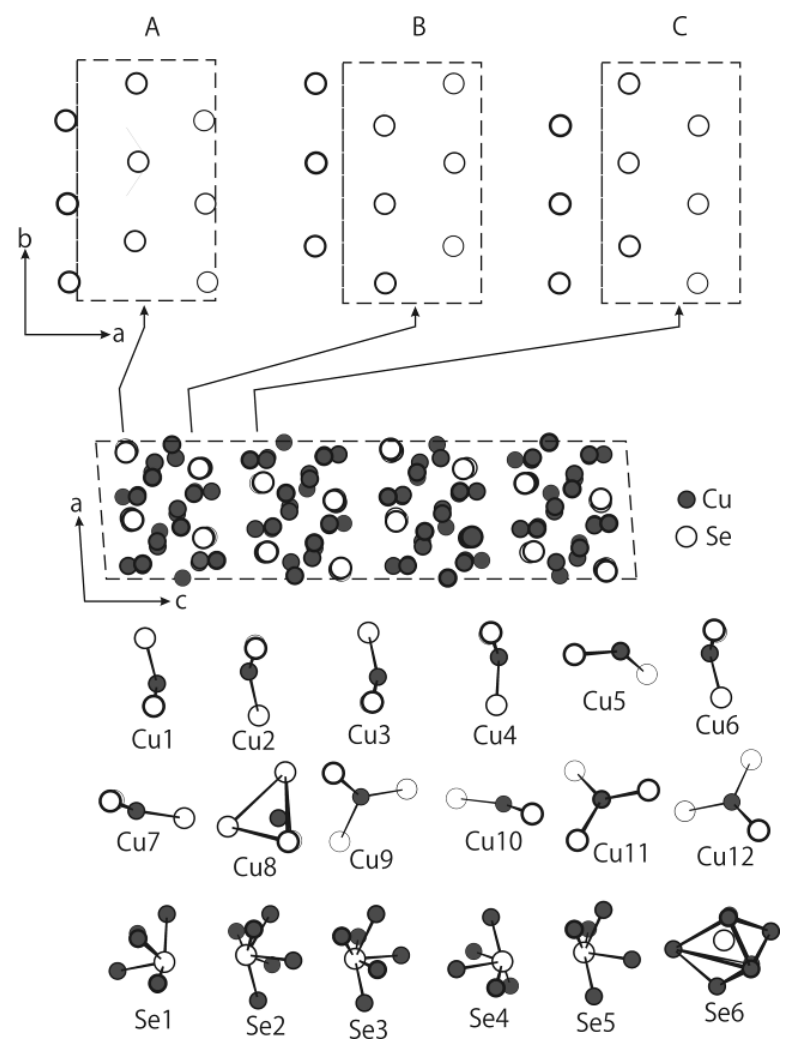

Fig. 3 Unit cell content and coordination polyhedra for $\mathrm{LT}-\mathrm{Cu}_{2} \mathrm{Se}$. 

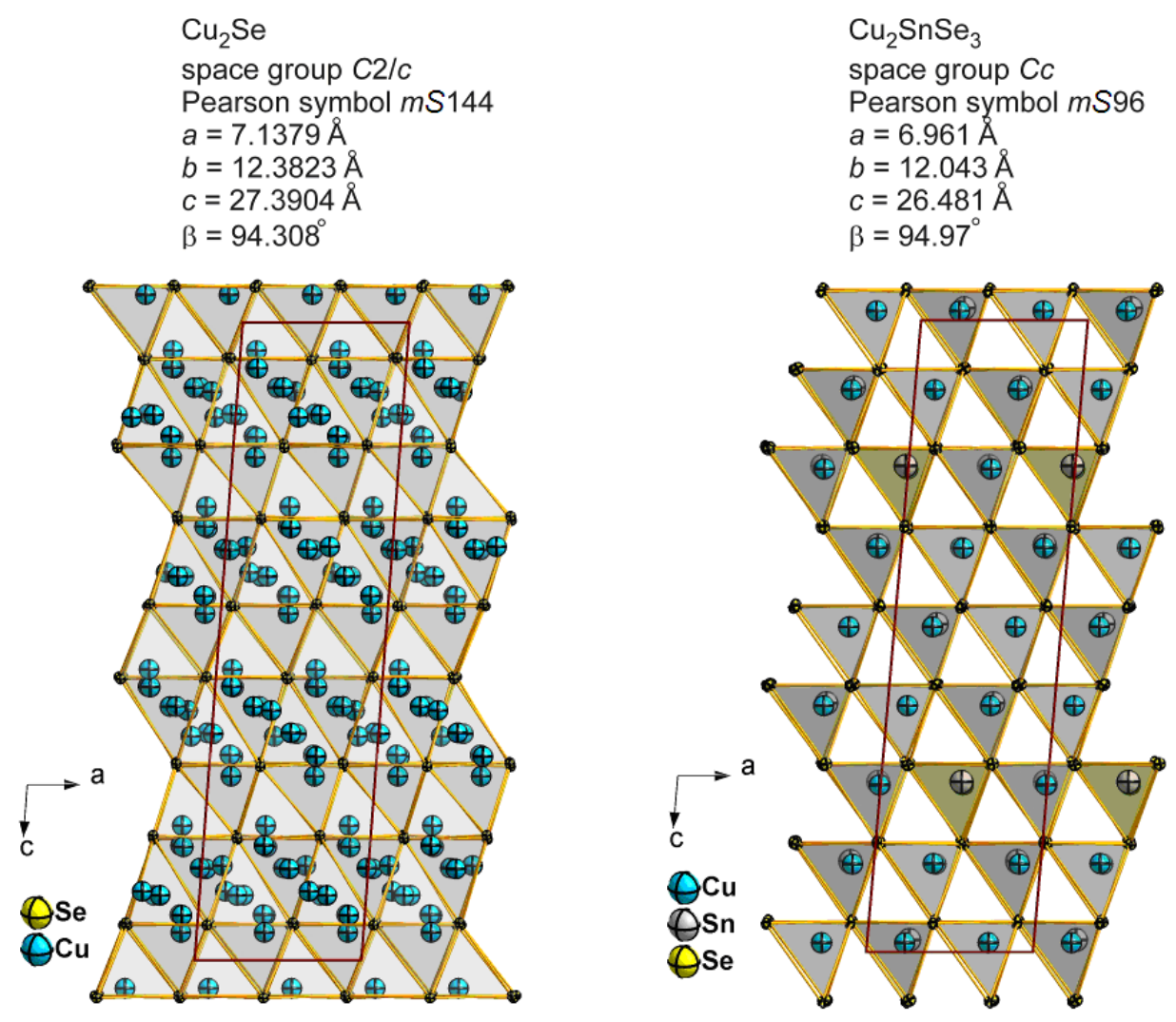

Fig. 4 Arrangement of Se tetrahedra and $\mathrm{Cu}$ and $\mathrm{Sn}$ atoms in the structures of $\mathrm{LT}-\mathrm{Cu}_{2} \mathrm{Se}$ and $\mathrm{Cu}_{2} \mathrm{SnSe}_{3}$.

Table 6 Interatomic distances $(\delta)$ and coordination numbers $(\mathrm{CN})$ of the copper atoms in the structure of $\mathrm{HT}-\mathrm{Cu}_{2} \mathrm{Se}$.

\begin{tabular}{ll|l|l}
\hline \multicolumn{2}{c|}{ Atoms } & \multicolumn{1}{c|}{$\delta(\AA)$} & \multicolumn{1}{c}{$\mathrm{CN}$} \\
\hline $\mathrm{Cu} 1$ & $-4 \mathrm{Se}$ & $2.5372(8)$ & 4 \\
\hline $\mathrm{Cu} 2$ & $-3 \mathrm{Se}$ & $2.404(1)$ & 3 \\
\hline $\mathrm{Cu} 3$ & $-3 \mathrm{Se}$ & $2.44(1)$ & 3 \\
\hline
\end{tabular}
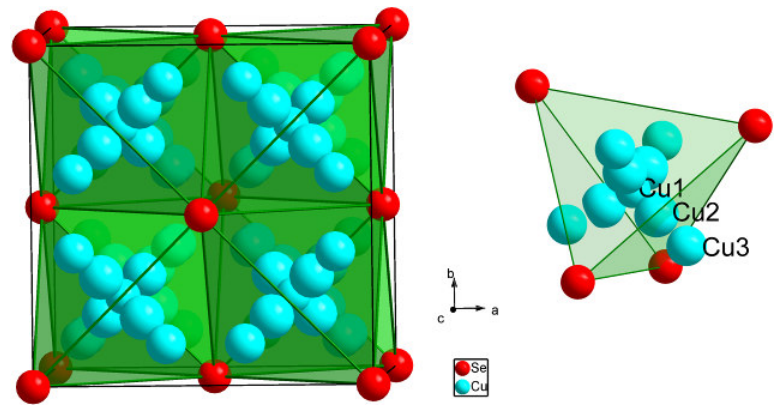

Fig. 5 Unit cell content and arrangement of $\mathrm{Cu}$ atoms in/near one $\mathrm{Se}_{4}$ tetrahedron in $\mathrm{HT}-\mathrm{Cu}_{2} \mathrm{Se}$.

The unit cell of the HT-phase of $\mathrm{Cu}_{2} \mathrm{Se}$ is shown in Fig. 5. The Se atoms are stacked in a close-packed arrangement with the layers in the sequence $A B C$. The $\mathrm{Cu} 1$ position is located exactly at the center of the tetrahedral interstice, whereas the $\mathrm{Cu} 2$ and $\mathrm{Cu} 3$ atoms are located close to a triangular face of the tetrahedron. The total occupancy of the copper sites is $0.31 \mathrm{Cu} 1+4 \cdot 0.14 \mathrm{Cu} 2+4 \cdot 0.03 \mathrm{Cu} 3=\sim 1$. Therefore, there are no empty tetrahedrons built by four selenium atoms in the lattice. Each tetrahedron is always occupied by a copper atom, however, the copper atom can be disordered in static or dynamic manner. The latter means that $\mathrm{Cu}^{+}$can easily drift among the $\mathrm{Cu} 1$, $\mathrm{Cu} 2$ and $\mathrm{Cu} 3$ positions inside the tetrahedron.

\section{Conclusions}

The structures of the low- and high-temperature modifications of $\mathrm{Cu}_{2} \mathrm{Se}$ have similar construction. The positions of the $\mathrm{Se}$ atoms in both modifications are ordered. The positions of the $\mathrm{Cu}$ atoms are ordered in the structure of the low-temperature modification, whereas they are disordered in the high-temperature modification.

\section{References}

[1] L.D. Gulay, M. Daszkiewicz, In: K.A. Gschneidner Jr., J.-C.G. Bünzli, V.K. Pecharsky (Eds.), Handbook on the Physics and Chemistry of Rare Earths, Vol. 41, Ch. 250, Elsevier B.V., Amsterdam, 2011, pp. 157-273. 
[2] K. Mitchell, J.A. Ibers, Chem. Rev. 102 (2002) 1929.

[3] R.M. Murray, R.D. Heyding, Can. J. Chem. 53 (1975) 878

[4] O. Milat, Z. Vučić, B. Ruščić, Solid State Ionics 23 (1987) 37.

[5] K. Yamamoto, S. Kashida, J. Solid State Chem. 93 (1991) 202.

[6] Oxford Diffraction, CrysAlis CCD and CrysAlis $R E D$, version 1.171.30.3, Oxford Diffraction Ltd, Abingdon, Oxfordshire, England, 2006.

[7] G.M. Sheldrick, SHELXS97 and SHELXL97, Programs for the Solution and the Refinement of Crystal Structures, University of Göttingen, Germany, 1997.
[8] L.G. Akselrud, Yu.N. Grun, P.Yu. Zavalii, V.K. Pecharsky, V.S. Fundamensky, Coll. Abstr. 12 Eur. Crystallogr. Meeting, Moscow, 1989, Vol. 3, 155 p.

[9] N. Wiberg, Lehrbuch der Anorganischen Chemie, Walter de Gruyter, Berlin, 1995, pp. 1838-1841.

[10] L.D. Gulay, M. Daszkiewicz, T.A. Ostapyuk, O.S. Klymovych, O.F. Zmiy, Acta Crystallogr. C 66 (2010) i58. 